\title{
Preparation, support and training requirements of South African expatriates
}

\author{
A.J. Vögel ${ }^{\star}$ and J.J. van Vuuren \\ Department of Business Management, University of Pretoria, \\ Lynnwood Road, Pretoria 0002, Republic of South Africa \\ Johan.Vogel@up.ac.za \\ S.M. Millard \\ Department of Statistics, University of Pretoria \\ Lynnwood Road, Pretoria, Republic of South Africa
}

Received June 2008

\begin{abstract}
A major issue in international human resource management is the failure of expatriates. The failure rate of expatriates has been reported to range anywhere between 10 and 80 percent, costing multinational enterprises (MNEs) between US\$40 000 and US\$1 million for each failed assignment. In order to address the problem it is recommended that MNEs provide sufficient preparation, support and training to not only the expatriate but also to their trailing spouses and children. This research has, however, proven that not only are South African MNEs not providing the preparation, support and training required by their expatriates, they are also falling short in the preparation, support and training provided to expatriate's trailing spouses and children. The research does, however, provide guidelines on the preparation, support and training that can be offered to expatriates, their trailing spouses and children.
\end{abstract}

*To whom all correspondence should be addressed.

\section{Introduction}

One of the most prominent issues in international human resource management is the failure of expatriates (Hill, 2005:624; Özbilgin, 2005:132; Black et al., 1991:291; Shaffer \& Harrison, 1998:87; Black, 1988:277). An expatriate can be defined as a person working and residing in a country other than their native country (Griffin \& Pustay, 2002:580) or according to Rugman and Hodgetts (2003:329), as home country nationals, who reside abroad but are citizens of the parent country of the multinational enterprise (MNE). Failure as defined by Hill (2005:624) refers to the premature return of an expatriate to his or her home country but as Shaffer and Harrison (1998:87 and Black, 1988:277) indicates, failure may vary in degree. They highlight the fact that expatriates who remain on the assignment but psychologically withdraw may incur indirect losses for their enterprise. These losses can include a reduction in productivity, market share, and competitive position, as well as damaged staff, customer and supplier relations, and a discredited corporate image and reputation.

Tung (1982:68) surveying United States (US), European and Japanese MNEs, highlighted the severity of the problem when identifying that 7 percent of US MNEs experienced expatriate failure rates of 10-40 percent, 69 percent had a recall or failure rate of $10-20$ percent, and the remaining 24 percent experienced a failure rate of less than 10 percent. Tung's (1982:68) work also suggested that US-based MNEs experienced a much higher expatriate failure rate than either
Western European or Japanese MNEs. More recently Shay and Tracey (1997:31) stated that 25 to 40 percent of US expatriates assigned to a developed country return home prematurely compared to 70 percent assigned to a developing country. This is supported by Briscoe and Schuler (2004:243-244) when stating that the rate of early return for US expatriates varies in different enterprises (and in different surveys) from 10 percent to 80 percent (with a common failure rate in the 30-40 percent range). Furthermore, according to Copeland and Griggs (in Shay \& Tracey, 1997:31) and Deresky (2002:398), it is estimated that between 30 and 50 percent of expatriates who do complete their assignments are considered ineffective or marginally effective.

Numerous authors have also highlighted the high cost of a failed expatriate assignment. According to authors such as McNerney (1996:1), Shay and Tracey (1997:31), Hill (2005:624), and Chowanec and Newstrom (1991:65), the estimated cost of a failed expatriate assignment range between US\$250 000 and US\$1 million. While authors such as Griffin and Pustay (2002:583) and Black (1988:277) estimate the cost of a failed expatriate assignment at between US\$40 000 and US\$250 000 (these figures include the expatriate's original training and moving expenses, as well as lost managerial productivity, but do not include the decreased performance of the foreign subsidiary itself). A failed assignment also has an indirect cost implication for a MNE as it can lead to damaged relations with the host country government, a diminished worldwide reputation of 
the MNE as well as negatively influencing the moral of employees in both the home and host country operations of an MNE (Chowanec \& Newstrom, 1991:66; Deresky, 2002:398).

According to Fontaine (1997:631), the success of international assignments could be ensured if effective preparation, support, and training were provided to the expatriate and their tailing families. Bross (in Anon 2000a:61) supports Fontaine (1997:631) in stating that it is important to select the right employees and then provide them with the proper cross-cultural training, support and services that will position them to be successful. Though stated somewhat differently, Black et al. (1991:293) identified five dimensions that has emerged as components of the cross-cultural adjustment process seen as important for expatriate success on an international assignment. According to them, the first three dimensions describe issues that exist before an expatriate leave their home country predeparture training, previous overseas experience and organisational selection mechanisms. The last two dimensions - individual skills and non-work factors - deals with issues that becomes relevant after the expatriate arrive at their foreign assignment.

The full extent of the problem in South Africa is, however, not known, as determining the failure rate, and the reasons for the failure of South African expatriates are predominantly done by research firms on behalf of individual MNEs or particular industries. As a result this information is treated as confidential. However, according to Muller (in Sapa, 2004), South African MNEs are falling short in terms of the structured training programmes they offer to expatriates, as well as on their repatriation upon completion of an international assignment. In light of the fact that the success of expatriates on an international assignment is influenced by the preparation, support and training they receive (Fontaine, 1997:631; Anon, 2000a:61; Black et al., 1991:293), the lack of such support could contribute towards the current and future failure of South African expatriates.

\section{Research objectives}

The objective of this research was to determine how South African MNEs should prepare, support and train their expatriates for international assignments. As was seen in the previous section, ill-prepared expatriates tend to fail come home from international assignments early - and as a result incur direct and indirect losses for their enterprises.

According to the second Global Expatriate Study (in Britt, 2002:22), nearly 40 percent of expatriates reported that they were not properly prepared for their international assignments. According to Fitzgerald-Turner (1997:72), and Black (1988:282), expatriates rarely receive any predeparture assistance apart from tax advice and the relocation of their household belongings. The lack of training has also been highlighted by other studies. It has been found that only about 30 percent of managers on expatriate assignments receive training before their departure (Hill, 2005:629; Briscoe \& Schuler, 2004:274; Deresky, 2002:399). As the literature seem to indicate that expatriates do not receive proper preparation support and training from their MNEs it was hypothesised that:

$\mathrm{H}_{10}$ : South African MNEs are not providing the preparation, support and training that expatriates feel they need for international assignments.

$\mathrm{H}_{1 \mathrm{~A}}$ : South African MNEs are providing the preparation, support and training that expatriates feel they need for international assignments.

According to Harvey (1995:223), one of the major issues for 64 percent of human resource managers surveyed, is the ability of a spouse and children to adapt to foreign locations. Harvey's (1995:223) research is supported by a study of PricewaterhouseCoopers (PWC) (in Anon, 2000b:80), who found that the partners of employees were the main reason for failed or unsuccessful postings in half the MNEs they surveyed. An early study by Tung (1982:67) has also found that the number one reason for the failure of expatriates in US and Western European MNEs were the inability of the expatriate's spouse to adjust to the foreign location. According to Sievers (1998:S9), the majority of MNEs do not have formal policies to address the needs of their expatriates' families, and that it is imperative that MNEs should develop comprehensive, flexible and interactive programmes specifically for spouses and children. Shay and Tracey (1997:33) indicates that only 12.5 percent of spouses in their study participated in training programmes designed to prepare expatriates and their families for an international assignment. As the literature seem to indicate that one of the main reasons for the failure of expatriates on international assignments is the inability of the spouse and/or trailing family to adapt to the new location it was hypothesised that:

$\mathrm{H}_{20}$ : Expatriates with spouses and children do not have special preparation, support and training needs.

$\mathrm{H}_{2 \mathrm{~A}}$ : Expatriates with spouses and children do have special preparation, support and training needs.

\section{Research methodology}

\section{Measuring instrument}

The research was started with a comprehensive literature study of the expatriation literature during which aspects related to the preparation, support and training of expatriates and their trailing families were investigated. This literature study was supplemented with a literature study of the expatriation policies of two international - non-South African - MNEs in order to ensure that a comprehensive though not exhaustive - list of preparation, support and training criteria could be determined with which an electronic questionnaire could be compiled. A website was then created hosting the questionnaire consisting of six demographic questions and 60 statements linked to a four point Likert-type scale. The 60 statements were divided as follows: 24 statements measuring preparation, 16 statements measuring support, seven statements measuring training, eight statements measuring spouses' needs and five statements measuring the needs of expatriates' children. 
The 60 statements were further split into two columns, one measuring what was provided to the expatriates and their trailing families and one measuring what they require from the MNE.

\section{The sample}

Non-probability judgment sampling was used, as only South African MNEs who make use of expatriates could be used in this study. The human resources managers of 48 South African MNEs were approached. These organisations were approached using phone calls, faxes, e-mails, personal visits and sometimes a combination of these methods in order to determine whether they made use of expatriates. Those that did were asked to participate in the research which required the MNE to provide a list of their expatriate managers as well as their e-mail addresses in order to forward the link to the website hosting the questionnaire to them. Only expatriates who were on an international assignment were included in the research as they were considered to be in the best position to respond to what they received and required in terms of preparation, support and training.

Of these 48 MNEs, five did not make use of expatriates. In total eight MNEs were willing to provide the e-mail addresses for their expatriates, and 102 links to the web site containing the questionnaire was sent out. Of these only 80 were still active addresses. A further six MNEs offered to send the link to the web site to their expatriate's personally, meaning that an undisclosed number of links was sent out by these MNEs.

Apart from the original 48 MNEs, one London-based enterprise specialising in expatriate research and other international human resource management (IHRM) matters, sent the link to the web site to its South African members with a letter asking them to participate in the research. As their membership records are confidential, no numbers or MNE names were divulged and as a result, again it is not known what the response from their members was. The end result of this process was a total of 65 respondents. This response is similar to the response rate in a study by Black (1988:283) studying US managers in Japan.

\section{Statistical analysis of the data}

The analysis of the data consisted of four phases. First the internal-consistency reliability of the measurement tool used in this study was tested using Cronbach's coefficient alpha. Secondly the Wilcoxon test was used in order to determine if there were any statistically significant differences between the preparation, support and training provided to expatriates and the preparation, support and training they require. Next, a paired $t$-test was used to test for statistical significant differences between provided versus required for each of the five section totals. Lastly, each respondent's Likert scale score for each variable for provided was deducted from their score for required. The mean score for the difference was then calculated and used to determine which variables had the biggest difference between provided and required in order to compile a rating for these variables.

\section{Limitations of the study}

The major limitation of this study was the small sample size. Only 65 usable responses were received, thus eliminating the option of a factor analysis.

\section{Results}

\section{Reliability}

In total there were 60 variables measuring the preparation, support and training provided to and required by South African expatriates, their trailing spouses and their children. Table 1 provides a summary of the Cronbach's alpha values of the variables measuring provided as well as required for each of the sections in the questionnaire. According to Cooper and Schindler (2003:216-217), a Cronbach's alpha value of above 0,5 is regarded as an indication of reliability. As can be seen all the values are above 0,7 indicating the reliability of the measurements.

\section{Demographic profile of the sample}

The ages of respondents varied from 23 to 60 years of age. The greatest number, namely 88,89 percent were male, while the largest percentage of respondents was married with 78 percent. Of the respondents the majority namely 30 hold top management positions, 27 hold middle management positions, while only five are in a supervisory position and three in non-managerial positions. The assignment durations varied in lengths from as short as seven months to as long as 120 months with the largest percentage, namely 38 percent lasting for 36 months, whilst 14,3 percent indicated that their international assignment would last for 24 months. Lastly the majority of the respondents namely 40 were assigned to Africa, 13 to Europe, eight to Asia and two to Australasia.

\section{Wilcoxon test results}

\section{Provided versus required}

When looking at the results of the Wilcoxon test for the individual variables it can be seen that there are statistically significant differences for all the variables. In other words, the mean scores for what expatriates required were higher than the mean scores for what they received for all the variables in the questionnaire.

On a 99 percent confidence interval when looking at the preparation of expatriates, 15 of the 24 variables scored a pvalue of $p<, 0001$, indicating statistical significance for the variables. As indicated in Table 2, for all the variables the mean scores for what was required was greater than the mean scores for what was provided.

When looking at the second section in the questionnaire support for expatriates - again all the variables showed statistically significant differences between what was provided and what was required. In fact, 12 of the16 variables in this section scored a $\mathrm{p}$-value of $\mathrm{p}<, 0001$, as can be seen in Table 3 . 
The importance of training expatriates for an international assignment is emphasised by the fact that all seven of the variables measuring the training of expatriates scored a pvalue of $\mathrm{p}<, 0001$, as can be seen in Table 4 below, indicating statistically significant differences between the training provided to expatriates and the training they require.

As was the case with the training of expatriates, all eight of the variables measuring what preparation, support and training was provided and should be provided to the trailing spouses of expatriates, scored high for statistical significance $(\mathrm{p}<, 0001)$, as can be seen from Table 5. Here to the mean scores for what was required were higher than the mean scores for what was provided.

The last section focused on the preparation, support and training of expatriates' children. In this section all the variables showed statistically significant differences between what was provided and what was required (Table 6).

After performing the Wilcoxon test on the individual variables, a paired $t$-test of the 5 sections in the questionnaire was performed. Table 7 provides a summary of these results.

\section{Table 1: Cronbach's alpha values}

\begin{tabular}{|c|c|c|}
\hline Sections & Provided & Required \\
\hline Cronbach's alpha results for Preparation (24 Variables) & 0,839459 & 0,819536 \\
\hline Cronbach's alpha results for Support (16 Variables) & 0,814811 & 0,773405 \\
\hline Cronbach's alpha results for Training (7 Variables) & 0,880700 & 0,849970 \\
\hline Cronbach's alpha results for Spouses (8 Variables) & 0,790118 & 0,802050 \\
\hline Cronbach's alpha results for Children (5 Variables) & 0,827206 & 0,782243 \\
\hline
\end{tabular}

\section{Table 2: Wilcoxon test for preparation required vs. provided}

\begin{tabular}{|c|c|c|c|c|}
\hline Variable & DF & Wilcoxon & P-Value & Rank \\
\hline Orientation visits to the international destination. & 52 & 17,0 & $<, 0001^{* *}$ & 13 \\
\hline Contact with expatriates currently at the international destination. & 50 & 27,0 & $<, 0001^{* *}$ & 6 \\
\hline $\begin{array}{l}\text { Accommodation in the host country equivalent to what the expatriate is accustomed to in the home } \\
\text { country. }\end{array}$ & 51 & 15,0 & $0,0281^{* *}$ & 23 \\
\hline List of property rental agents in the host country. & 51 & 11,0 & $0,0002^{* *}$ & 16 \\
\hline Assistance with negotiating a property lease agreement. & 50 & 20,5 & $0,0071^{* *}$ & 20 \\
\hline Expatriates should be allowed to buy a house in the host country. & 51 & 37,5 & $<, 0001^{* *}$ & 11 \\
\hline Shipping arrangements of household goods should be made on behalf of the expatriate. & 48 & 15,0 & $0,0019^{* *}$ & 17 \\
\hline The MNE should pay for shipping and insurance expenses. & 51 & 2,0 & $0,0625^{*}$ & 24 \\
\hline The MNE should pay for storage and insurance of household goods left in the home country. & 51 & 12,0 & $0,0002^{* *}$ & 18 \\
\hline MNEs should limit shipping and insurance costs. & 51 & 69,5 & $0,0585^{*}$ & 22 \\
\hline $\begin{array}{l}\text { If furnished accommodation is available the MNE should pay for the storage of the expatriate's } \\
\text { belongings. }\end{array}$ & 51 & 46,0 & $0,0256^{* *}$ & 21 \\
\hline The MNE should ship an expatriate's personal automobile to and from the assignment destination. & 51 & 7,5 & $<, 0001^{* *}$ & 15 \\
\hline $\begin{array}{l}\text { The MNE should reimburse the expatriate for losses due to the early sale or lease cancellation of an } \\
\text { automobile. }\end{array}$ & 51 & 8,5 & $<, 0001^{* *}$ & 4 \\
\hline The expatriate should receive assistance with the rental of a primary residence in the home country. & 50 & 37,5 & $<, 0001^{* *}$ & 12 \\
\hline The expatriate should receive assistance with the sale of a primary residence in the home country. & 51 & 8,5 & $<, 0001^{* *}$ & 14 \\
\hline Reimburse the expatriate for losses due to the sale of a home in the home country. & 51 & 7,0 & $<, 0001^{* *}$ & 5 \\
\hline Pay for the shipping expenses of pets. & 51 & 14,0 & $<, 0001^{* *}$ & 8 \\
\hline Legal assistance with drawing up or updating a will. & 51 & 46,5 & $<, 0001^{* *}$ & 9 \\
\hline Provide tax consultation prior to departure. & 51 & 0,0 & $<, 0001^{* *}$ & 1 \\
\hline Provide a full medical and dental examination prior to departure. & 51 & 12,0 & $<, 0001^{* *}$ & 7 \\
\hline The MNE should cover hotel expenses prior to departure. & 50 & 21,5 & $0,0015^{* *}$ & 19 \\
\hline Discuss the expatriate's long-term career path prior to departure. & 50 & 28,5 & $<, 0001^{* *}$ & 2 \\
\hline A mentor should be assigned to an expatriate. & 51 & 31,0 & $<, 0001^{* *}$ & 3 \\
\hline Provide reading material from the host country prior to departure. & 51 & 55,5 & $<, 0001^{* *}$ & 10 \\
\hline
\end{tabular}

Statistical significance, $\alpha=0,1^{*}$ and $\alpha=0,05^{* *}$ 
Table 3: Wilcoxon test for support required vs. provided

\begin{tabular}{|c|c|c|c|c|}
\hline Variable & DF & Wilcoxon & P-Value & Rank \\
\hline The MNE should provide a tour of the new location upon arrival. & 51 & 4,0 & $<, 0001^{* *}$ & 4 \\
\hline $\begin{array}{l}\text { Provide expatriates with assistance with opening a bank account and } \\
\text { obtaining a drivers licence. }\end{array}$ & 51 & 0,0 & $<, 0001^{* *}$ & 12 \\
\hline $\begin{array}{l}\text { Cover temporary living expenses prior to moving into long-term } \\
\text { accommodation. }\end{array}$ & 51 & 0,0 & $0,0078^{* *}$ & 16 \\
\hline Once-off relocation allowance for miscellaneous expenses upon arrival. & 50 & 6,0 & $0,0001^{* *}$ & 13 \\
\hline Furniture/appliance allowance if shipping of these goods was unpractical. & 51 & 5,0 & $<, 0001^{* *}$ & 9 \\
\hline Provide the same quality of medical aid cover. & 51 & 7,5 & $<, 0001^{* *}$ & 10 \\
\hline Provide a list of reputable doctors and dentists in the host country. & 51 & 0,0 & $<, 0001^{* *}$ & 1 \\
\hline Assistance with setting up expatriate clubs/organisations in the host country. & 51 & 0,0 & $<, 0001^{* *}$ & 3 \\
\hline The MNE should pay for club memberships in the host country. & 51 & 0,0 & $<, 0001^{* *}$ & 2 \\
\hline Provide plane tickets to the home country for home leave. & 51 & 9,0 & $0,0255^{* *}$ & 15 \\
\hline Provide plane tickets to the home country to visit sick relatives. & 50 & 0,0 & $<, 0001^{* *}$ & 7 \\
\hline Pay for the packaging and shipping of household goods upon repatriation. & 50 & 0,0 & $0,0039^{* *}$ & 14 \\
\hline $\begin{array}{l}\text { The MNE should pay the customs duties on purchased goods upon returning } \\
\text { to the home country. }\end{array}$ & 51 & 26,0 & $<, 0001^{* *}$ & 8 \\
\hline The MNE should pay excess baggage penalties of expatriates. & 51 & 10,0 & $<, 0001^{* *}$ & 6 \\
\hline Provide temporary accommodation upon repatriation. & 50 & 0,0 & $<, 0001^{* *}$ & 11 \\
\hline $\begin{array}{l}\text { Expatriates should receive a once-off settlement allowance upon } \\
\text { repatriation. }\end{array}$ & 50 & 0,0 & $<, 0001^{* *}$ & 5 \\
\hline
\end{tabular}

Statistical significance, $\alpha=0,1^{*}$ and $\alpha=0,05^{* *}$

\section{Table 4: Wilcoxon test for training required vs. provided}

\begin{tabular}{|c|c|c|c|c|}
\hline Variable & DF & Wilcoxon & P-Value & Rank \\
\hline Inform expatriates of the local driving practices in the host country. & 51 & 0,0 & $<, 0001^{* *}$ & 6 \\
\hline $\begin{array}{l}\text { Provide the expatriate and his/her family with a security briefing on the host } \\
\text { country. }\end{array}$ & 51 & 4,5 & $<, 0001^{* *}$ & 1 \\
\hline Provide an overview on doing business in the host country. & 51 & 0,0 & $<, 0001^{* *}$ & 4 \\
\hline Provide objective cross-cultural training for expatriates. & 51 & 7,0 & $<, 0001^{* *}$ & 2 \\
\hline Provide subjective cross-cultural training for expatriates. & 51 & 6,5 & $<, 0001^{* *}$ & 3 \\
\hline Provide language training where a different language is spoken. & 51 & 6,5 & $<, 0001^{* *}$ & 5 \\
\hline $\begin{array}{l}\text { Present a repatriation seminar for the expatriate and his/her family prior to } \\
\text { repatriation. }\end{array}$ & 50 & 18,0 & $<, 0001^{* *}$ & 7 \\
\hline
\end{tabular}

Statistical significance, $\alpha=0,1^{*}$ and $\alpha=0,05^{* *}$

\section{Table 5: Wilcoxon test for required vs. provided for trailing spouses}

\begin{tabular}{|c|c|c|c|c|}
\hline Variable & DF & Wilcoxon & P-Value & Rank \\
\hline $\begin{array}{l}\text { Spouses should attend an information and orientation session prior to } \\
\text { accepting the assignment. }\end{array}$ & 40 & 0,0 & $<, 0001^{* *}$ & 5 \\
\hline $\begin{array}{l}\text { Spouses should receive assistance with obtaining a work permit in the host } \\
\text { country. }\end{array}$ & 39 & 0,0 & $<, 0001^{* *}$ & 1 \\
\hline Aid the spouse in finding work in the host country. & 40 & 0,0 & $<, 0001^{* *}$ & 2 \\
\hline $\begin{array}{l}\text { The MNE should provide trailing spouses with work if they cannot find } \\
\text { other employment. }\end{array}$ & 39 & 0,0 & $<, 0001^{* *}$ & 8 \\
\hline The MNE should pay for the spouse's further studies. & 40 & 0,0 & $<, 0001^{* *}$ & 7 \\
\hline Spouses should receive objective cross-cultural training. & 40 & 0,0 & $<, 0001^{* *}$ & 3 \\
\hline Spouses should receive subjective cross-cultural training. & 40 & 0,0 & $<, 0001^{* *}$ & 4 \\
\hline $\begin{array}{l}\text { Spouses should receive language training where a different language is } \\
\text { spoken in the host country. }\end{array}$ & 40 & 0,0 & $<, 0001^{* *}$ & 6 \\
\hline
\end{tabular}

Statistical significance, $\alpha=0,1^{*}$ and $\alpha=0,05^{* *}$ 
Table 6: Wilcoxon test for required vs. provided for expatriate children

\begin{tabular}{|c|c|c|c|c|}
\hline Variable & DF & Wilcoxon & P-Value & Rank \\
\hline $\begin{array}{l}\text { Expatriates should receive an education allowance (tuition only) for their } \\
\text { children's schooling. }\end{array}$ & 25 & 0,0 & $0,0625^{*}$ & 5 \\
\hline $\begin{array}{l}\text { Plane tickets should be provided for children in a tertiary institution in the } \\
\text { home country. }\end{array}$ & 25 & 0,0 & $0,0039^{* *}$ & 4 \\
\hline Provide objective cross-cultural training for children. & 25 & 0,0 & $0,0005^{* *}$ & 1 \\
\hline Provide subjective cross-cultural training for children. & 25 & 0,0 & $0,0010^{* *}$ & 3 \\
\hline $\begin{array}{l}\text { Provide language training for children where the host country language is } \\
\text { different from the home country language. }\end{array}$ & 25 & 0,0 & $0,0010^{* *}$ & 2 \\
\hline
\end{tabular}

Statistical significance, $\alpha=0,1^{*}$ and $\alpha=0,05^{* *}$

Table 7: Paired $t$-test section totals

\begin{tabular}{|c|c|c|c|}
\hline Provided versus required & DF & $t$-Value & $\operatorname{Pr}>|t|$ \\
\hline Preparation provided versus required & 44 & 9,61 & $<, 0001^{* *}$ \\
\hline Support provided versus required & 47 & 10,23 & $<, 0001^{* *}$ \\
\hline Training provided versus required & 50 & 9,17 & $<, 0001^{* *}$ \\
\hline Provided to spouses versus required by spouses & 38 & 10,13 & $<, 0001^{* *}$ \\
\hline Provided to children versus required by children & 25 & 4,24 & $0,0003^{* *}$ \\
\hline
\end{tabular}

Statistical significance, $\alpha=0,1^{*}$ and $\alpha=0,05^{* *}$

In all five the above-mentioned sections the mean score for what was required was higher than the mean score for what was provided.

As the results of the Wilcoxon and $t$-tests have shown statistical significant differences between the preparation, support and training required versus provided in all five of the sections tested in the questionnaire, the null hypothesis $\mathrm{H}_{10}$ : South African MNEs are not providing the preparation, support and training that expatriates feel they need for international assignments - is accepted.

\section{Spouse and family needs}

The Wilcoxon test was also used in determining whether expatriates with trailing spouses and children have special needs when on an international assignment. Table 5 above lists all the variables in the questionnaire testing the requirements of expatriates with trailing spouses with each variable's p-value. As can be seen from Table 5, all the variables showed statistically significant differences between what was provided and what was required, with $\mathrm{p}$ values of $\mathrm{p}<.0001$. For all the variables the mean scores for what was required were higher than the mean scores for what was provided.

There is also statistical significance between the mean score for the preparation, support and training provided to the expatriates' trailing spouse and the mean score for the preparation, support and training required by the expatriate's trailing spouse for all the variables combined in the fourth section of the questionnaire as can be seen in Table 7 (Provided to spouses versus required by spouses) $(t$-value $=$ $10,13 ; \mathrm{p}<, 0001)$.

As was seen in Table 6, the last five variables in the questionnaire focused on the preparation, support and training needs of expatriates with children. At a significance level of $p \leq 0,05$ all but one variable in this section show statistically significant differences between what was provided and what is required, as the mean scores for what was provided were lower than the mean scores for what was required.

When looking at the paired $t$ - and p-values for all the variables in the last section in Table 7 , it can be seen that there is statistical significance in the difference between the mean score for the preparation, support and training provided to the expatriates' children and the mean score for the preparation, support and training required by the expatriates for their children (Provided to children versus required by children) ( $t$-value $=4,24 ; \mathrm{p}=0,0003)$.

As there are statistically significant differences in all the variables in both sections, the null hypothesis $-\mathrm{H}_{20}$ :

Expatriates with spouses and families do not have special preparation, support and training needs - is rejected. But the alternative hypothesis $-\mathrm{H}_{2 \mathrm{~A}}$ :

Expatriates with spouses and families do have special preparation, support and training needs - is accepted.

\section{Discussion}

When looking at the literature it becomes clear that though the preparation, support and training of expatriates are important for the success of an international assignment, not many MNEs provide this to their expatriates. This fact was also supported by the findings of this study for South African MNE.

Internationally it would seem that predeparture tax advice and the relocation of an expatriate's household belongings are the minimum assistance provided by an MNE (Fitzgerald-Turner, 1997:72). Considering this, it was interesting to note that South African expatriates were least likely to receive predeparture tax consultation services and most likely to have the MNE pay for the shipping and insurance expenses of their household belongings. 
Two other important findings were that expatriates do not know their long-term career path within the MNE (rating of two), and mentors are not being assigned to expatriates while on an international assignment (rating of three). According to authors such as Allen and Alvarez, (1998:34 35); Briscoe and Schuler, 2004:251 and Rugman and Hodgetts (2003:334) these are key factors in improving an MNEs' repatriation success rate. These findings support those of Muller (in Sapa, 2004) who found that South African MNEs are falling short in terms of the repatriation of expatriates upon completion of their international assignments.

Authors such as Hanrehan and Bentivoglio (2002) and Briscoe and Schuler (2004:382) states that family members accompanying employees on an international asignment have always been a major focus of international HR programmes, and the September 11 terrorist attacks and the conflict in Afghanistan have increased concerns for their safety. The findings of this research have shown that South African expatriates are no different with security briefings of the host country being the training requirement that showed the biggest difference between what expatriates require and what they are receiving.

The study also found that the biggest gap between what was provided to and required by spouses were the fact that MNEs' were not providing trailing spouses with assistance in obtaining a work permit in the host country and secondly were not aiding spouses in obtaining a job in the host country. This issues was also highlighted internationally by Sievers (1998:S9), who added that the issue of spouse's employment grows more significant as the number of dual career couples rises. This might not only lead to an increase in failed expatriate assignments for South African MNE but also to a reluctance of key employees to accept international assignments.

In terms of the expatriates' children's needs the biggest gap was the fact that expatriates did not feel that MNE's were providing sufficient objective cross-cultural training to their children. This training would help them understand the objective components of a host country's culture focussing on issues such as: the host country's currency, language and government system. With the inability of an expatriate's spouse and trailing family to adjust to the host country being one of the most important reasons for expatriate failure in international studies, this is an area that MNE should pay close attention to.

\section{Conclusion}

A study of the international expatriate literature has shown that the preparation, support and training of expatriates for international assignments can reduce the possibility of a failed expatriate assignment. However, numerous international studies have shown that MNE are not offering their expatriates the preparation, support and training required to improve the likelihood of a successful international assignment.

A lack of similar research in South Africa meant that the current state of preparation, support and training offered to South African expatriates was not known. The lack of similar South African research further complicated the study as it meant that the problem statement needed to be based on US and European findings.

The findings of this study can be considered important for two reasons; firstly, it confirms that South African expatriates are in the same position as their counterparts from the USA and Europe in that they are not receiving the preparation, support and training they require. Secondly, the research identifies the specific preparation, support and training needs of South African expatriates enabling South African MNE to compare their policies with the requirements of these expatriates. Unfortunately a focus on how the preparation, support and training should be conducted falls outside the scope of this article.

\section{References}

Allen, D. \& Alvarez, S. 1998. 'Empowering expatriates and organisations to improve repatriation effectiveness', Human Resource Planning, 21(4): 29-39.

Anon. 2000a. 'Getting smart about going global', Workforce, 79(7): 58-61.

Anon. 2000b. 'Nasty, brutish and short: International assignments: Managing expatriates', The Economist, December: 80-82.

Black, J.S. 1988. 'Work role transitions: A study of American expatriate managers in Japan', Journal of International Business Studies, 19(2): 277-294.

Black, J.S., Mendenhall, M. \& Oddou, G. 1991. 'Towards a comprehensive model of international adjustment: An integration of multiple theoretical perspectives', Academy of Management Review, 16(2): 291-317.

Briscoe, D.R. \& Schuler, R.S. 2004. International human resource management. 2nd Edition. London: Routledge Taylor \& Francis Group.

Britt, J. 2002. 'Expatriates want more support from home', HR Magazine, 47(7): 21-22.

Chowanec, G.D. \& Newstrom, C.N. 1991. 'The strategic management of international human resources', Business Quarterly, 56(2): 65-70.

Cooper, D.R. \& Schindler, P.S. 2003. Business Research Methods. 8th Edition. New York: McGraw-Hill Irwin.

Deresky, H. 2002. International management: managing across borders and cultures. 4th Edition. Upper Saddle River: Prentice Hall.

Fitzgerald-Turner, B. 1997. 'Myths of expatriate life', HR Magazine, 42(6): 65-74.

Fontaine, G. 1997. 'Skills for successful international assignments to, from and within Asia and the Pacific: Implications for preparation, support and training', Management Decisions, 35(8): 631-642. 
Griffin, R.W. \& Pustay, M.W. 2002. International business: A managerial perspective. 3rd Edition. Upper Saddle River: Prentice Hall.

Hanrehan, B. \& Bentivoglio, D.R. 2002. Safe haven: Accommodating the needs of employees and families in hostile environments can increase expenses and alter tax liability. [Online] URL: http://web4.infotrac.galegroup.com/itw/inf.../purl=rc1_GBI M_0_A83058910\&dyn=26!xrn_1_0_A83058910?sw_aep $=u$ p_it.

Harvey, M.G. 1995. 'The impact of dual-career families on international relocations', Human Resource Management Review, 5(3): 223-244.

Hill, C.W.L. 2005. International business: Competing in the global marketplace. 5th Edition. New York: McGraw-Hill Irwin.

McNerney, D.J. 1996. 'Global staffing: Some common problems - and solutions', HR Focus, 73(6): 1-6.

Özbilgin, M. 2005. International human resource management, theory and practice. New York: Palgrave Macmillan.

Rugman, A.M. \& Hodgetts, R.M. 2003. International business. 3rd Edition. Harlow: Prentice Hall.

Sapa. 2004. SA expats less keen to go home than counterparts. [Online] URL: http://www.pretorianews.co.za/index.php?fSectionld=665\&f Articleld=2106312.

Shaffer, M.A. \& Harrison, D.A. 1998. 'Expatriates' psychological withdrawal from international assignments: Work, nonwork and family influences', Personnel Psychology, 51(1): 87-118.

Shay, J. \& Tracey, J.B. 1997. 'Expatriate managers: Reasons for failure and implications for training', Cornell Hotel and Restaurant Administration Quarterly, February: 30-35.

Sievers, C. 1998. 'Work/family: Key to a successful assignment', HR Focus, 75(3): S9-S10.

Tung, R.L. 1982. 'Selection and training procedures of U.S., European, and Japanese multinationals', California Management Review, 25(1): 57-71. 